\title{
Serbia's Orientation Challenge and Ways to Overcome It
}

\section{Vesna Pavičić}

Ministry of Security of Bosnia and Herzegovina, http://msb.gov.ba/

\begin{abstract}
Serbia, the largest country of the Western Balkans, faces a historical choice concerning its future political orientation. Although this choice has been on the agenda since the late 1990s, it will remain unresolved for some time to come. The country's transformation has been moving forward. However, short of integration in western institutions, first of all in the European Union, the process is incomplete and other major players in the international system, first of all Russia but to some extent also China, attempt to influence Belgrade in a direction favorable to their interest. Rational choices in regard to economic integration, trade and investment, and the effects of consolidating democracy should drive Serbia in the direction of the West. However, as demonstrated by some cases, there are factors other than rational choice. Emotional association with Russia, orthodox Christianity, the Russian backing of Serbia in the dispute of the latter with Kosovo, as well as Moscow's sophisticated influence playing on the West's step-by-step advancement and hesitation help Russia better establish itself in Serbia. That results in an inconclusive situation that requires attention to avoid the continuation of hesitancy and uncertainty in the long run. China potentially offers an alternative, primarily as a trade partner and investor. However, its interests in Serbia's future orientation may be different from Moscow's as its investments may offer higher returns if Belgrade becomes a member of the European Union sooner rather than later.
\end{abstract}

Keywords: European Union, Russian Influence, Serbia, Western Balkans, China. 


\section{Introduction}

This article aims to address the historical challenge and dilemma that Serbia has been facing for some time and will face for the years to come. It has to complete its democratic transition as one of the complex challenges. Domestic democratization must go hand in hand with the continuation of modernization as well as continuing alignment with the West and integration in institutions that would further contribute to the consolidation of Serbia's transformation. However, it would be premature to conclude that Serbia has irrevocably settled in the West as it weighs options and some of its partners appear to offer alternatives.

The fundamental attributes of national identity, i.e., "a) historic territory or homeland; b) common myths and historical memories; c) common mass public culture; d) common legal rights and duties for all members; and e) common economy with territorial mobility for members," are playing an important role in Russia's political rhetoric towards Serbia. ${ }^{1}$ Ethno-national belonging appears to be the crucial mainstay and differentiation variable of social identification of the members of the largest national communities in Serbia. ${ }^{2}$ It is essential to decide which attributes-material or immaterial-matter more in the identity-building. Another important matter is whether those attributes are objective or perceptional, whether they are present in society or being "built" through official and societal discourses. Finally, it is a question of whether external players can contribute to identity-shaping by either directly reaching out to Serbia's society or by influencing its political establishment. If we assume that external players' presence in Serbia plays a major role in shaping the latter's identity, then we have to contemplate which of them is based on what. The political division between its "western" and "eastern" identity continues to be a challenge to the external perception of Serbia as an actor on the international political scene.

Serbia's pro-European orientation has been clearly present since the beginning of the century and the departure of the regime of Slobodan Milosevic from office and power. However, doubts have remained as far as backing the verbal commitment by action and by taking the painful decisions that have been apparently necessary. Hence, the outcome has remained questionable. In 2003, when the EU provided a membership perspective to the Western Balkans, organized criminality demonstrated its power by executing the Prime Minister of Serbia. The assassination of Prime Minister Zoran Đinđić was one of the factors that "influenced a shift in the vector of Serbia's foreign policy towards the East." ${ }^{3}$ The responsibility for war crimes of the 1990s was another factor. The fact that many

1 Antoni D. Smit, Nacionalni Identitet (Belgrade: Biblioteka XX vek, 1998), 29-30.

2 Jovan Komšić, Dragomir Pantić, and Zoran Đ. Slavujević, Osnovne Linije Partijskih Podela i Mogući Pravci Političkog Pregrupisavanja u Srbiji (Belgrade: Friedrich Ebert Stiftung, Institute of Social Sciences, 2003), 55-77.

3 Helsinki Committee for Human Rights in Serbia, "The Warp of the Serbian Identity: Anti-westernism, Russophilia, Traditionalism," Ogledi i Studies No. 17 (Belgrade, 2016), 188, https://www.helsinki.org.rs/doc/Studies17.pdf. 
in Serbia regarded the severe punishments to Serbian perpetrators as "Siegerjustiz" representing a disbalance sentencing Serbs but much fewer Croats and Bosniaks also contributed to the perception of the "unfairness of the West." These are some of the reasons for Belgrade pursuing a declaratory pro-western political orientation without contemplating full engagement and excluding other options. Belgrade's delivery has remained questionable. Today, it is an ambiguously aligned country, where political elites gravitate to different directions and orientate themselves to various power centers.

The countries of the Western Balkans are still facing the challenging process of consolidation. With significant variation, they are often simultaneously interested in engagement with Western states and Russia, while the China factor is also present in their economies. Some of them have completed the process of EU or/and NATO integration, but Russia's influence is visible in their politics. It is more often in doubt whether Russia is also present in their economic sphere. As will be demonstrated later, Moscow's economic engagement is quite limited in terms of bilateral trade with Belgrade (and also with others). However, and this is when one has to return to the question of various attributes of presence and influence, Moscow's presence is highly visible and underlined by symbolism.

\section{Serbia Looks to the EU - The EU Hesitantly Looks Back}

Despite that the European Union is "not as attractive as it used to be," Serbia still hopes to join the EU. That was confirmed in 2016 by then prime minister Aleksandar Vučić's statement (now the President of Serbia): "We are rational people and we know this is the best for our country." ${ }^{4}$ The Serbian prime minister also stated in 2016 that a "large majority of Serbian citizens favor the continuation of the European path while maintaining close ties with China and Russia." ${ }^{5}$ However, the question of how long Serbia would be able to balance between the West and the East without compromising its EU accession prospects still remains. The noticeable disappointment of Serbia is due to a series of factors. Since the democratic transition at the beginning of the century, followed in 2003 by the EU providing "European perspective" to the Western Balkans, occurred half a generation ago. In June 2003, in Thessaloniki, the EU-Western Balkans summit approved the declaration endorsed by the European Council. The declaration stated: "The future of the Balkans is within the European Union. The ongoing enlargement ... inspire and encourage the countries of the Western Balkans to follow the same successful path." ${ }^{6}$ Although the EU's commitment remained

4 More on this matter: "Vucic Says EU Membership Has 'Lost Magic Power' for Balkans," Radio Free Europe/Radio Liberty, February 23, 2016, http://www.vucic-says-eumembership-has-lost-magic-power-for-balkans-migrant-crisis-brexit.

5 Reuters online: https://www.reuters.com/article/us-serbia-election/serbias-vucicconfirms-domination-with-presidential-win-idUSKBN1733VI.

6 Declaration, EU-Western Balkans Summit, C/03/163, Thessaloniki, June 21, 2003, 10229/03 (Presse 163), point 2. 
vague and did not mention any timeline, still some states in the Western Balkans must have been under the impression that the perspective will be realized faster.

A decade later, when the EU Commission of Jean-Claude Juncker was formed, the incoming Commission President stated the following: "In the next five years, no new members will be joining us in the European Union. ... However, the negotiations will be continued and other European nations and European countries need a credible and honest European perspective. This applies especially to the Western Balkans." 7 Five years have passed, and with the Commission leaving office, it can be stated that if there was one promise that Juncker held, it was that there was no further enlargement of the EU during those five years. Closer to the end of the office term, the EU may have noticed that the absence of tangible enlargement prospect reduces $E U$ influence in the region and only increases the influence of other powers. Hence, a Communication issued in February 2018 reaffirmed the vague promise in somewhat clearer terms: "Accession negotiations are already well underway with Montenegro and Serbia. With strong political will, the delivery of real and sustained reforms, and definitive solutions to disputes with neighbors, they could potentially be ready for membership in a 2025 perspective. This perspective is extremely ambitious. Whether it is achieved will depend fully on the objective merits and results of each country." 8 Formally, EU enlargement hardly got closer and that makes the doubts of politicians, diplomats, NGOs, and scholars concerning the accession of any country of the Western Balkans to join the EU by 2025 understandable. ${ }^{9}$

Certain developments indicate no breakthrough as far as enlargement in the Western Balkans. The number of chapters closed or opened in the accession talks with Belgrade has risen to two provisionally closed and 17 opened chapters out of $35 .{ }^{10}$ As the negotiations have been going on since 2014 , this illustrates piecemeal advancement. However, it is important to mention that economic re-

7 Jean-Claude Juncker, Candidate for the President of the European Commission, "A New Start for Europe (Speech/14/567)," Strasbourg, July 15, 2014, http://europa.eu/ rapid/press-release_SPEECH-14-567_en.htm.

8 Communication from the Commission to the European Parliament, the Council, the European Economic and Social Committee and the Committee of the Regions, "A Credible Enlargement Perspective for and Enhanced EU Engagement with the Western Balkans," Strasbourg, February 6, 2018, COM(2018) 65 final, https://ec.europa.eu/ commission/sites/beta-political/files/communication-credible-enlargementperspective-western-balkans_en.pdf.

9 Julija Simić, "Serbia in the EU in 2025 - Mission (Im)possible," Euractiv.rs, April 5, 2019, https://www.euractiv.com/section/enlargement/news/serbia-in-the-eu-in-2025mission-impossible.

10 As of the end of May 2019. See Commission Staff Working Document, Serbia 2019 Report, accompanying the document "Communication from the Commission to the European Parliament, the Council, the European Economic and Social Committee and the Committee of the Regions: 2019 Communication on EU Enlargement Policy," COM (2019) 260 final, Brussels, May 29, 2019, SWD(2019) 219 final, 4, https://ec.europa.eu/neighbourhood-enlargement/sites/near/files/20190529serbia-report.pdf. 
lations have also intensified. As of 2017, the EU is Serbia's single largest trade partner, representing more than 60 percent of both its export and import. Its trade exceeds every other partner's by almost 8:1 ratio in import and 11:1 ratio in export compared to the second largest. Regarding import, Serbia's secondlargest partner is China (8.1 percent); in export, it is the Russian Federation (5.9). In sum, the EU has no alternative in the external trade of Serbia. The situation is even more tilting in the direction of the $\mathrm{EU}$ as far as the inflow of foreign direct investment (FDI) in the period 2010-2017, representing approximately 73 percent of the total. The second-largest investor is Russia, representing less than 10 percent. The cumulative FDI of the EU is seven and a half times higher than that of the Russian Federation. ${ }^{11}$ In sum, if we assess Serbia's situation exclusively based on economic rationality, the EU has no alternative. However, this information should reach the large portion of the Serbian population that may be affected by other considerations, influenced by messages addressing emotions and solidarity with reference to identity matters. Moreover, even on purely economic considerations, it has to be taken into account that some of the trade, FDI, and other kinds of acquisition is concentrated in certain strategic branches of the economy like energy (Russia) and telecommunications (China) that may affect the perception of economic dependency.

It is also important to note that the EU commitment to Serbia as a candidate country is going beyond trade and investment. Namely, Serbia is the "largest recipient of EU donations in the Western Balkans and one of the largest in the world." 12 This is understandable in light of the fact that Serbia is the largest economy and the most populous country of the Western Balkans, and it is difficult to imagine a next EU enlargement in the region without Belgrade's accession. The European Union is the biggest donor of Serbia "with more than EUR 3 billion in non-refundable aid over the past 15 years, ... and the country's number one partner in supporting development and ongoing reforms." The grants provided over the past 15 years aimed to contribute to development in all fields, ranging from the rule of law, public administrative reform, social development, education, environment, the improvement of the infrastructure, and agriculture. ${ }^{13}$

It is clear that there are problems with Serbia's advancement to EU membership on both sides. The most important among them are listed below:

1. The EU's hesitation is due both to factors that stem from Serbia's situation and others that are unrelated. As far as Serbia is concerned, it certainly does not

11 The Delegation of the European Union to the Republic Serbia, FDI to Serbia, Imports to Serbia, Exports from Serbia, http://europa.rs/serbia-and-the-eu/trade/fdi-inserbia/?lang=en; http://europa.rs/serbia-and-the-eu/trade/serbia-total-imports/ ?lang=en; http://europa.rs/serbia-and-the-eu/trade/serbia-total-exports/?lang=en.

12 The Delegation of the European Union to the Republic Serbia, "EU and Serbia at Work," http://europa.rs/eu-assistance-to-serbia/eu-and-serbia-15-years-of-partner ship/?lang=en.

13 The Delegation of the European Union to the Republic Serbia, "EU and Serbia at Work." 
help that the country's lasting political orientation, including the anchoring of the country in the West, is not so unequivocal as was in the case of East-central European states when they first demonstrated their aspiration to settle in the West and become EU (and NATO) members in the 1990s. The country's international political orientation should be exempted from party politics, at least as a strategic objective. There are other matters where improvement could be more persuasive, such as reducing the level of corruption, good governance, and others.

2. The EU's hesitation is also due to matters not related to Serbia. The late1990s period was characterized by enthusiasm in European politics; politicians were under the impression that Europe is on the way to unification and lasting peace. At the end of the 2010s, many in Europe are skeptical, Europe gives the impression of a re-divided continent, and the Western Balkans may be the last unsettled area in addition to some former Soviet republics (Ukraine and Georgia). There is no lasting peace on the European continent. There is a geopolitical rivalry between the West and Russia. Also, some new EU members that joined since 2004 did not deliver particularly well on their promises. Checks and balances are not respected, the judiciary's independence is violated, human rights are undermined by measures like the domination of the media by a few loyal actors and cronies, political power is used for the enrichment of members of the political establishment, and the unceasingly high level of corruption, among others. Understandably, the EU does not want to make another big mistake and integrate states that do not deliver on promises after gaining membership. The EU does not want to see further members, which regard membership as a "cash cow" while not delivering on some of the foundational values of the Union and taking solidarity on critical matters.

The fact that the EU has managed the Western Balkans enlargement as a routine matter since the issuance of the February 2018 document has been due to various factors. It is the single most important reason that the EU was busy with other matters ranging from BREXIT to the discord concerning migration and some notorious members challenging agreed values. Furthermore, the change of guard in several leadership positions, including the EU Commission, the European Parliament, the European Council, and the European Central Bank, diverted the attention away at least temporarily. In parallel, the so-called Berlin mechanism, dedicated to addressing the Western Balkans, has been fading due to Germany's diminishing commitment. Whether the EU under the new leadership will make enlargement in the Western Balkans a priority remains to be seen.

Serbia has strong reservations towards NATO underlined by the 78 nights of bombardment in March-June 1999. It is also a country that regularly reasserts to keep its neutrality. However, this does not mean that it has no relations with the Atlantic Alliance. It participates in Partnership for Peace (PfP), has signed an Individual Partnership Programme (IPAP), and joins exercises with NATO member states. Hence, it can be concluded that Serbia has been pursuing a vectoral foreign and security policy within limits. While Serbia's NATO membership is not a 
current issue and the situation will not change any time soon, it is a question whether Belgrade's security situation could be influenced in any other manner. There is one regional issue that is closely linked with Serbia's security. Namely, as Belgrade approaches the EU and will possibly become an EU member in the next decade, the problem is how to avoid a sharp divide between Serbia and Bosnia and Herzegovina. It is clear that with its current performance and constitutional system, Sarajevo cannot become an EU member. However, if Belgrade becomes an EU member without any perspective for Bosnia and Herzegovina, the Bosnian Serbs will have two options: to become Serbian citizens as individuals or join Serbia with the territory of the Republika Srbska. Although NATO membership would not resolve this problem, it might alleviate it. ${ }^{14}$

Similar to earlier enlargements, it is essential to keep the strategic importance and political attention since, without it, the drive will dissipate in the hands of technocrats. This has already been the impression of various forces in the Western Balkans. ${ }^{15} \mathrm{~A}$ strategic approach would probably contribute to drawdifferent conclusions regarding the timeframe and some of the detailed conditions of accession. However, it raises a delicate question: To what extent should the EU compromise accession conditions in the name of recognition that it is part of a geopolitical rivalry first of all with the Russian Federation. This also raises the question of to what extent the candidates could instrumentalize the strategic importance of enlargement and hence change the discourse to their advantage. It is certain that both parties are aware of the dilemma and regard the approach to enlargement as an instrument.

\section{Russia's Counter-interests and Its Means}

The Russian Federation has never left the Western Balkans. Its presence has been steady, although its intensity, emphasis, and ramifications of Russian politics have changed since the 1990s. Ever since the wars in former Yugoslavia came to an end, the Russian interest focused on a continuing commitment without sacrificing large material resources or, for that matter, the best people over there. This attitude may be due to the recognition that the small and mediumsize states of the Western Balkans are less important than the great powers with which Moscow identifies itself as being in the same league or the traditionally higher importance assigned to the other successor states of the Soviet Union.

The relations between Russia and the Western Balkans are based on similar foundations:

14 I do not deny that such a solution is "the second best." It would be certainly better to overcome the legacy of Dayton and put Bosnia and Herzegovina on the road to EU membership. However, this may be an illusion under the current conditions.

15 For the best overview of such a position see European Movement Serbia and Embassy of the Federal Republic of Germany in Serbia, "Twelve Proposal for EU Enlargement from the Western Balkans" (Belgrade, June 2018), http://www.emins.org/wpcontent/uploads/2018/06/Twelve-Proposals-web.pdf. 
1. Political engagement is based on different discourses in accordance with the expectations of the receiving country and its population.

2. Identity politics is an essential part of it. In Croatia, it is about Slavonic roots; in Serbia, this is complemented with an emphasis on Orthodox Christianity, and the same goes for the Serbs in other countries of the region.

3. The Russian presence and contribution are amplified by tailor-made media messages. Russia has invested in this by the Serbian language news program of RT and Sputnik news. The latter is reaching out to communities in various languages. They often support the politicians in power in the respective states, undermine the credibility of the opposition, speak about their brutality when rebelling, ${ }^{16}$ and attempt to alienate the population from the West. ${ }^{17}$

4. Distortion of history also plays a role, including the presentation of an exaggerated role of the Soviet Union in the liberation of Yugoslavia in World War II. The difficulties that characterized Soviet-Yugoslav relations of the late-1940s are erased from history, whereas Russian support to Serbia in the Dayton peace arrangement and even more in the socalled Kosovo war of 1999 are often emphasized.

5. The Russian-Western Balkans relations are often visualized by symbolic high-level meetings in the Croat, Serbian and Bosnian Serb context. This includes presidential meetings, including a high profile visit of President Putin to Serbia in 2019. Such a visit is of high-visibility and includes liturgical elements.

6. In the Serbian context, a state that, unlike most states of the Western Balkans, is neither member of NATO nor approaching it, cooperation has an important symbolic military component, including Russian military assistance.

7. Russian political support also extends to Serbia as far as its claim of Kosovo belonging to Serbia.

8. The Russian economic footprint is relatively small overall. Western Balkans' trade with Russia equals approximately 4 percent of the total, including 3.1 percent of export and 4.9 percent import. ${ }^{18}$

16 See the report of RT on the behavior of anti-government protesters in Belgrade: "Serbian Anti-govt Protesters Break through Police Cordon \& Block Presidential Palace," RT, March 17, 2019, https://www.rt.com/news/454071-serbia-vucic-protestpolice/.

17 It suffice to mention the extensive reports of Sputnik News on wide-spread lewd behavior in the West, including homosexuality and nudity, that intend to alienate many Muslims. See https://sputniknews.com/tags/tag_Albania/.

18 See Eurostat, "Western Balkans Countries-EU - International Trade in Goods Statistics," Eurostat: Statistics Explained, May 2019, https://ec.europa.eu/eurostat/ 
In sum, the Russian presence in the Western Balkans has a mixed foundation, including the strengths and weaknesses listed above. Serbia belongs to those states which, due to size, historical and religious links (and some of its mystification), and its pending Kosovo dispute, attract the prime attention of Moscow. With this, an impression is created as if Moscow would present an alternative for Belgrade. If we take a closer look at some of those factors, the picture becomes more nuanced.

1. The relatively low intensity of economic relations between Russia and the Western Balkans generally and with Serbia specifically, in terms of both trade and investment, does not mean Russia's insignificance in the relationship.

- In Serbia, Russian-owned or indirectly linked firms control close to 13 percent of the national economy's revenues.

- Direct dependence is complemented by indirect elements, like dependence on Russian raw materials, export to Russia, and debt for gas supply.

- Serbia is heavily dependent upon gas supply by Gazprom and largely dependent upon oil supply by Lukoil. Local political intermediaries prevent the diversification of the energy markets.

- Gas dependence will further increase due to transit linked to the continuation of Turkish Stream and cooperation with Russia in supplying parts of Serbia with liquefied natural gas where pipelines do not reach habitations.

- Russian loan schemes contribute to the dependency. ${ }^{19}$

- Russian state-owned Sberbank entered Serbia's market in 2012 and purchased the "banking arm of Volksbank International in Central and Eastern Europe." 20

2. The Russian connection is highly visible in military matters. Serbian officers study at Russian defense academies. The Serbian military conducts exercises with the Russian military. Since 2013 Serbia has observer status with the Collective Security Treaty Organization (CSTO) and has a "military cooperation agreement with Russia in place which allows Russian soldiers to be based at Niš airport." 21 Last but not least, Serbia has received Russian armaments and equipment from Russia, including BRDM-2 reconnaissance and patrol vehicles, T-72 battle tanks, and MiG-29 combat aircraft. Even though this looks impressive, in

statistics-explained/index.php?title=Western_Balkans-EU_-_international_trade_in_ goods_statistics\&oldid=480316.

19 Centre for the Study of Democracy (CSD), "Assessing Russian Economic Footprint in Serbia," Policy Brief no. 72, January 29, 2018, https://csd.bg/publications/publica tion/policy-brief-no-72-assessing-russias-economic-footprint-in-serbia, 1.

20 CSD, “Assessing Russian Economic Footprint in Serbia," 12.

21 Official site of the Ministry of Defence of Republic of Serbia, http://www.mod.gov.rs/ lat/11655/unapredjenje-standarda-i-modernizacija-vojske-prioriteti-ministarstvaodbrane-11655. 
fact, they are fairly dated pieces, and in the case of the MiG-29s the modernization costs have to be borne by Serbia.

3. Russia gives diplomatic backing to the power holders in Belgrade that is essential when the leadership is challenged. Although this is expressed in somewhat ambiguous terms, like when Russian Foreign Minister Sergey Lavrov confirmed that Russia is extremely interested in the long-term stability and prosperity of the entire Western Balkans region, it has still been pronounced. ${ }^{22}$ This could only be regarded as a cynical statement just a few months after the Russian Federation attempted a coup d'etat against the elected leaders of Montenegro, and while it made attempts to drive wedges between political forces in (as it is now called) the Republic of North Macedonia. However, Russia is certainly interested in the stability of Serbia as it is unlikely that instability (or any turbulence) would be to Moscow's benefit.

Taken together, the Russian Federation lastingly intends to remain part of the Western Balkans equation. Its attention focuses on states, which have not been firmly anchored in the West regarding institutional alignment in the EU and NATO. Other factors, like the economic possibilities, certainly also play a role, e.g., it has kept Russian interest in Croatia as an investor in the agroindustry and elsewhere. Serbia is at the intersection of these two factors. Russia's primary intention is to prevent the completion of the western integration of the entire region. Towards that purpose, Moscow uses various means, including fully legal, morally questionable, illegitimate, and outright illegal ones. With such a combination of various means, it has succeeded in contributing to the impression that Serbia is not a lastingly and irrevocably settled country as far as its political orientation. With its limited means, this is the maximum that Russia may hope to achieve. With limited means, it is difficult to be a major positive contributor. However, it may be sufficient to be a spoiler, in particular when the West continues to be hesitant in expeditiously moving forward with completing the Western Balkans' integration.

\section{China as a Complementary Complicating Factor}

The Russian Federation is an actor that, lastingly and by a complex set of means, attempts to influence Western Balkans' politics. This is understandable, as it regards the region as the last unsettled area of Europe. Russia has difficulties accepting that some sovereign states in the area of the former Soviet Union may also like to define their own future rather than accepting Russia's tutelage. Although the Western Balkans' gradual approach to the West is undeniable, as long

22 Ministry of Foreign Affairs of the Russian Federation, "Foreign Minister Sergey Lavrov's remarks and answers to media questions at a news conference following talks with Deputy Prime Minister and Minister of Foreign and European Affairs of Croatia Davor Ivo Stier, Moscow, May 23, 2017," www.mid.ru/en/web/guest/meropriyatiya_ s_uchastiem_ministra/-/asset_publisher/xK1BhB2bUjd3/content/id/2763697. 
as the process is not completed, Russia feels to have a chance to strain its muscles.

China had no particular interest in the region after the break-up of Yugoslavia. However, with its global economic expansion that finally reached the whole of Europe during the last years of the 2010s, when due to the global financial crisis, the old continent became more attractive, the Western Balkans also reached China's attention threshold. With the One Belt One Road (now Belt and Road) Initiative and later with $16+1(17+1)$, explicitly dedicated to East-central and South-eastern Europe, China has taken more active interest. The interest has remained focused on the economy and does not seem to go beyond the economic relaitons. Of course, economic interaction is dependent on political stability. The view that Beijing gives preference to cooperation with political systems that are similar to China's is widespread in the West, yet difficult to substantiate. Nevertheless, there is evidence that:

- China, as a trading and investment partner, is more corrupt than most western economies;

- China prefers inter-governmental relations in its transactions and creates lasting dependencies that make it interested in lasting political stability;

- $\quad$ The majority of its enterprises are state-owned, whereas the 35 percent share of privately-owned companies (that does not include the largest ones) are also dependent upon the Chinese political authorities.

In the Western Balkans, the concerns emanating from the previous points, including that many politicians in the region are not immune to corruption, are complemented by the size of the economies. They may easily become dependent upon a large partner, like China, as an investor and a loan provider. China is a mixed blessing for the non-EU members in the Western Balkans as Chinese investment does not have to meet the EU requirements to reduce financial opaqueness, contribute to transparency, and meet certain standards as far as profitability and environmental concerns. The experiences of some countries in South Asia and Africa should serve as warning signals.

The situation varies from country to country in the Western Balkans ranging from highly indebted Montenegro with 78 percent of its sovereign debt per GDP to Serbia, where it reaches only 12 percent. Serbia attracted more than 2.5 billion euro Chinese projects, among which the largest is the modernization of the railroad connection between Belgrade and Budapest, ${ }^{23}$ a project surrounded by doubts as far as profitability. However, as it is also representing 44 percent of the region's non-EU economies, it is less endangered to be dominated by China than its smaller regional partners. It seems Belgrade is fairly careful with Chinese

${ }^{23}$ Valbona Zeneli, "China in the Balkans: Chinese Investment Could Become a Challenging Factor for the European Future of the Western Balkans," The Globalist, April 9, 2019, https://www.theglobalist.com/Balkans-china-fdi-belt-and-road-eu. 
investment and loans that it regards as expressions of neo-colonialism. It remains to be seen whether this will change in light of the Chinese promises and the adoption of two relevant Chinese documents, the Guiding Principles on Financing the Development of the Belt and Road Initiative and the Debt Sustainability Framework for Participating Countries of the Belt and Road Initiative. ${ }^{24} \mathrm{Alt}$ hough China did not recognize Kosovo's declaration of independent statehood, its presence in Serbia (just as generally in the Western Balkans) has retained its economic focus and the Chinese support to Serbia did not become highly visible. Although this might change in the future, it is necessary to note that the economic aspect is currently the nearly exclusive focus of China's advancement in the Western Balkans. Beijing's growing overall influence without a major change in its policy and without far more direct EU influence may create problems as far as the spread of good governance in the Western Balkans. This may in turn undermine the chance of EU enlargement and its benefits both for the EU and the inhabitants of the states of the Western Balkans.

\section{The Kosovo Quagmire: An Aggravating Factor}

Kosovo moved from de facto to de jure independence with its declaration of independent statehood in February 2008, recognized by many ${ }^{25}$ as Belgrade could no longer credibly argue for multi-ethnicity. Serbia has not been able to find a solution to this matter in cooperation with Kosovo. As Belgrade is not in the position to officially take note of Kosovo's independence, it has retained its revanchist attitude. That does not mean it would be ready to use forceful means to reverse the status quo. Yet, for Serbia, the issue is undecided. History teaches us that states with revanchist aims (except for the world's strongest powers) usually try to find support for their aspirations. This creates allegiances and dependency on their supporters. Many states fell into this trap in history and paid dearly for their mistake. As the Russian Federation has openly supported Serbia in its aspiration to "regain" its territorial integrity, Moscow has contributed to a dependency that both states find advantageous. If we go back to the roots of the matter, it is clear that UN Security Council Resolution 1244, adopted upon the end of the Kosovo war, left ambiguity concerning the territorial status of Kosovo. ${ }^{26}$ This was due, among others, to the essential contribution of the Russian Federation to bringing about a resolution that entailed the end of the military conflict fought by NATO against Belgrade.

24 Amine Bennis, "China's Inroads into the Balkans," The World Today (Chatham House, June-July 2019), https://www.chathamhouse.org/publications/twt/china-s-inroadsbalkans.

25 Overall, during the first ten years after the declaration of independence (February 2008) 117 states recognized Kosovo. See https://www.kosovothanksyou.com.

26 Resolution 1244 (1999), adopted by the Security Council at its 4011th meeting, on June 10, 1999, S/RES/1244 (1999), https://digitallibrary.un.org/record/274488. 
Russia's veto power in the UN Security Council used to block the furthering of Kosovo's statehood made Serbia's foreign policy linked to Russia. In 2008, the Serbian government decided that its policy priorities would be the preservation of the country's territorial integrity, meaning also the retention of Kosovo, and also EU integration. Such an approach contributed to creating "a two-vector foreign policy," which represents bipolar communication "balancing between Brussels and Moscow, and it became the constant of all Serbian governments." 27 Regardless of "its official commitment to EU integration, the Serbian Government ... continued to pursue the foreign policy of both EU and Russia." 28

The progress of normalization has remained somewhat inconclusive. Serbia and Kosovo signed two agreements towards normalizing ties upon strong encouragement and facilitation of the EU. "Following the EU brokered deals in 2013 and 2015, relations with Serbia seem to be normalizing, but independence did not necessarily bring about democratic and accountable governance." ${ }^{29}$ EU officials assessed the signing of the agreements in Brussels as "the key step in normalizing relations between Serbia and Kosovo, but also as mandatory precondition for move along to EU integration." 30 The EU's influence continued to bring Serbia and Kosovo to the negotiating table. However, in January 2018, the leader of Serbs in Kosovo was gunned down in Mitrovica on the day talks should have restarted between the two parties. ${ }^{31}$ This has indicated opposition to the reconciliation process. The ambiguous declaration of the EU reflected in the press as some vague promise that Serbia and Montenegro may become members of the Union in 2025 had an impact on the parties. ${ }^{32}$ Kosovo could conclude that the settlement of its status through its recognition as an independent state will be more urgent to Belgrade, as it is apparent that Serbia cannot become an EU member without it. As we know, the party feeling the urgency would be more willing to seek compromise. This resulted in miscalculation. To make the long story short, Belgrade continued to block Pristina's membership in certain international organizations, whereas the latter introduced a hundred percent customs duties for Serbian and Bosnian and Herzegovinian products that de facto meant that they had no chance in the market in Kosovo. Finally, to facilitate a sustainable solution, the idea has emerged to resolve some of the contentious

27 Helsinki Committee for Human Rights in Serbia, The Warp of the Serbian Identity, 191.

28 Helsinki Committee for Human Rights in Serbia, The Warp of the Serbian Identity, 191.

29 Lana Pašić, "Democracy, 25 years after Yugoslavia," openDemocracy, April 3, 2016, https://www.opendemocracy.net/can-europe-make-it/lana-pasic/democracy-25years-after-yugoslavia.

30 Dušan Vučićević, "Parlamentarni Izbori u Srbiji 2016," Političke Analize 7, no. 25 (2016), 26.

31 John R. Schindler, "Mysterious Balkan Assassination Threatens Regional Peace," Observer, 16 January 2018, http://observer.com/2018/01/assassination-of-oliverivanovic-threatens-peace-in-balkans.

32 Communication from the Commission to the European Parliament, "A Credible Enlargement Perspective," point 5.1. 
issues between Serbia and Kosovo by exchanging territories. However, this would mean a departure from the position of the so-called Contact Group held since the early years of the $21^{\text {st }}$ century. There are countries, which actively support such a solution, like the United States; others, like France, are hesitant, and some fear chaos, e.g., Germany. The matter is also divisive in domestic politics as some leaders support it, such as the President of Kosovo, while others, like the country's long-time prime minister, opposed it. Short of consensus, the matter remains without resolution.

The Russian Federation never said it would not recognize the statehood of Kosovo; rather, Russia expressed the view that it would join an arrangement that Serbia finds acceptable. In the second half of the decade, Moscow started to notice that solving the matter of Kosovo statehood may be approaching. This would reduce Russian influence in the Western Balkans. Moscow initiated a variety of measures in order to prevent this unfavorable development. Russia offered its readiness to mediate between the parties in order to undermine the EU monopoly in Serbia-Kosovo relations. However, it was apparent that Russia only wants to delay the process and gain influence. Moscow also started to promote the withdrawal of recognitions to Kosovo's statehood actively. Overall, in the second half of the 2010s, 14 small states withdrew Kosovo's state recognition. This has been regarded as a success in Belgrade, while Russia, understandably, did not advertise its role in the process. ${ }^{33}$

During the first half of the 2010s, Serbia's government measured the change of public opinion and considered if and when the recognition of statehood could be offered to Kosovo. ${ }^{34}$ In July 2015, 72 percent of the Serbian population believed that Serbia would be compelled to recognize Kosovo in order to join the European Union, while 57 percent held the view that Serbia should refuse to accept that even if it means staying out of the EU. The population's decreasing will to join the EU is shown in the following statistic: 76 percent supported EU integration in October 2009, 71 percent in August 2010, 69 in April 2011. By November 2015, this percentage decreasing to $49 .{ }^{35}$ Surveys conducted in 2019 show that 78 percent of the respondents would not support the decision to recognize Kosovo's independence in exchange for Serbia becoming an EU member faster. At the same time, 27 percent of the respondents think that the government of Serbia will recognize Kosovo's statehood. These findings are particularly interesting, given that 47 percent of the respondents think that Kosovo has been

33 The website listing the recognitions of Kosovo provides no information of the recognitions withdrawn. See www.kosovothanksyou.com.

34 Centre for Insight in Survey Research, "Survey of Serbian Public Opinion: November 24 - December 3, 2015," http://www.iri.org/sites/default/files/wysiwyg/serbia_ november_2015_poll_public_release.pdf.

35 Centre for Insight in Survey Research, "Survey of Serbian Public Opinion." 
lost for Serbia. ${ }^{36}$ It is important to closely follow the tendencies as Serbian politicians may be reluctant to put their future at risk at the price of recognizing Kosovo, while it is hard to imagine the continuation of the EU enlargement process with Serbia without such recognition. However, the monitoring of the public opinion may not matter exclusively for Serb politicians, but EU officials and politicians of the member-states as well. It would result in a strange situation if, close to the accession talks, the EU "wakes up" and concludes that the population of Serbia (and hence the political class) is reluctant to pay the price for the accession by recognizing the de facto territorial status quo.

\section{Ways to Mitigate This Dilemma - Conclusions}

Bearing in mind Serbia's still existing orientation toward the European Union, the integration process should be accelerated. Efforts by both sides, EU and Serbia, should be focused on increasing understanding of democracy and European identity. The political dialogue needs to be intensified in security, political, and economic frameworks for developing Serbia's security and socio-economic system in a clear direction. The development of the country, increasing the standard of living, providing for more transparency and freedom of the press, changing political rhetoric will eventually facilitate the transition process and EU integration.

Strengthening civil society's role in free media promotion and protection will weaken hate speech and obstructions to democratic processes. "The role of media is central in the life of many people in Serbia ..." and the European Union should use mechanisms to support "free and independent media in Serbia, as well as bringing back (or indeed introducing) to the country international media outlets." ${ }^{37}$ The role of the media in building public opinion is unquestionable. Also, investment in adequate education of the youth will prepare future generations to understand democratic standards and preserve them.

Even the fact that "the Serbian public has expressed its dissatisfaction with EU conditionality," the European Union should bring back its reputation and "clarify Serbia's requirements regarding Kosovo" and "accommodate sensitive issues in Serbia in the accession process," ${ }^{38}$ otherwise, Russia and China would show the broader interest to improve their "unconditional" cooperation. More flexibility and clear dialogue regarding critical issues could allow progress. Europe should consider the possible consequences for Europe more seriously due

36 "Većina građana Srbiji smatra da je Kosovo traino izgubljen," SEEbiz, March 31, 2019, accessed November 23, 2018, http://rs.seebiz.eu/vecina-gradana-srbije-smatra-daje-kosovo-trajno-izgubljeno/ar-191944.

37 European Parliament, "Serbia's Cooperation with China, the European Union, Russia and the United States of America," EP/EXPO/B/AFET/2017/09 (Directorate-General for External Policies, Policy Department, November 2017), 44, https://www.euro parl.europa.eu/cmsdata/133504/Serbia\%20cooperation\%20with\%20China,\%20the\% 20EU,\%20Russia\%20and\%20the\%20USA.pdf.

38 European Parliament, "Serbia's Cooperation with China," 45-47. 
to the presence of different geopolitical interests in the Balkans rather than creating strict, often technical conditions for membership. Further delay of the integration of all remaining Western Balkan countries could result in the loss of the region. However, the states of the western Balkans, which aspire for EU membership, should also find ways to more effectively fight those phenomena that form obstacles to EU membership (including corruption and weak governmental capacity).

Continuous tensions in the region demand intensive engagement and a stronger presence of the United States, but also the encouragement of the European Union for the accession of Western Balkan countries. United States programs to strengthen economic growth, the rule of law, and fight against corruption remain important for the Euro-Atlantic integration of the region, ${ }^{39}$ but insufficient. Strengthening political dialogue and the more active engagement of the US leadership in the Balkans is much needed.

Therefore, it could be another possibility that "the EU and U.S. need a joint strategy which should include common policy to address regional security threats, clear EU and NATO membership perspective as well as the development of a common energy policy." ${ }^{40}$ Currently, this may be problematic as the US and the EU, as well as some EU larger members, have many other divisive issues on the agenda that would make it difficult to overcome and refocus the attention to the Western Balkans. However, the US seems to have a clear idea how to overcome the Serbia-Kosovo stalemate, and its contribution may be indispensable over there. The common interest of the West and the Western Balkans countries should be to support stability, economic development, democratic transition, and re-empowering integration in the EU.

A secure environment may contribute to an increase in foreign investment, which would positively impact development. The state should increase public awareness regarding the importance of the EU and its benefits and implications on Serbia's future socio-economic development. Serbia's EU integration is also urgent in protecting it from a foreign intervention that would lead the country and, with it, the region into political stagnation and isolation. Today Serbia's foreign policy relies on four major external powers: the European Union, the United States, the Russian Federation, and China. In the short-term, Serbia can sustain an "unstable equilibrium." However, further progress towards EU accession could mean that Serbia will have to "sacrifice some independence in foreign af-

39 John McCain, "The Balkans Are Heating Up Again - and Washington Is Nowhere to Be Seen," The Washington Post, April 27, 2017, https://www.washingtonpost.com/ news/democracy-post/wp/2017/04/27/the-balkans-are-heating-up-again-andwashington-is-nowhere-to-be-seen/.

40 Ernst M. Felberbauer and Predrag Jureković, "A Region in Limbo: South East Europe in the Light of Strained Western-Russian Relations," Study Group Information Band 26/2015 (Republic of Austria, Federal Ministry of Defense and Sports, September 2015), https://www.bundesheer.at/wissen-forschung/publikationen/publikation.php ?id=936, 114-115. 
fairs." ${ }^{41}$ The EU, in turn, should find ways to be far more visible in Serbia, and in the Western Balkans more broadly, and "sell better" its essential contribution to the development of the region.

It is essential to understand Russia's role in attempting to destabilize the Balkan region that is hidden behind the pan-Slavic political rhetoric. Russia's excellence in shaping the identity of Serbia's population could be a message to the European Union about its ineffectiveness and inability to do the same. The strategic partnership "justified" on the basis of economic cooperation is not realistic in light of the distance between Serbia and Russia, and also due to the fact Serbia already conducts most of its trade and foreign direct investment with the EU countries.

If Serbia wishes to join the European Union, balancing between Brussels and Moscow has to be stopped. "The Western Balkans has become part of the new geopolitical competition." ${ }^{42}$ The European Union's foreign policy is the one that should be followed. On the other hand, Brussels should do its best not to allow further Russian obstruction of European and Euro-Atlantic integration in the future. Russia's strength in Serbia is the EU's weakness.

\section{Disclaimer}

The views expressed are solely those of the author and do not represent official views of the PfP Consortium of Defense Academies and Security Studies Institutes, participating organizations, or the Consortium's editors.

\section{Acknowledgment}

Connections: The Quarterly Journal, Vol. 18, 2019 is supported by the United States government.

\section{About the Author}

Vesna Pavicic is a civil servant in the Ministry of Security in Bosnia and Herzegovina. Since 2018 she has been serving in the OSCE Special Monitoring Mission (SMM) in Ukraine.

41 European Parliament, "Serbia's Cooperation with China," 1-38.

42 Felberbauer and Jureković, "A Region in Limbo," 114. 